\title{
Language Choice as a Technology of Talk: A Case Study of Thai Teacher Trainees
}

\author{
Freek Olaf de Groot (เฟรก โอลาฟ เดอ โกรท) \\ вNU-н кв U United International College, Zhuhai, China \\ freekolaf@uic.edu.hk
}

\begin{abstract}
This paper discusses the ways Thai teacher trainees of English conceptualize their language choices inside the classroom, the affordances and constraints this creates for their learning and how it affects their identifications as teacher trainees. Drawing on data from a longitudinal ethnographic study in central Thailand, this paper describes how language choice functions as a 'technology of talk' (Jones 2016) that creates both affordances and constraints for our social interaction and the ways our identity is negotiated in social interaction in the classroom. It demonstrates that language choice, in societies in which our literacy practices are increasingly mediated by digital technology, is not only conceptualized through discourses on the situated appropriateness of literacy practices in the classroom, but also influenced by an extended network of digital literacy practices students engage outside the classroom. These digital literacy practices afford new ways of expressing, doing and saying in languages that are otherwise scarcely accessible outside the classroom. Engaging in these practices constructs networks of widely dispersed literacy practices forming intricate nodes between both online and offline sites and gradually permeate traditionally bounded spaces such as the classroom.
\end{abstract}

\section{Keywords}

technologies of talk - language choice - Mediated Discourse Analysis - teacher identity 
บทคัดย่อ

การเลือกภาษาคือเทคโนโลยีในการพูดคุย: กรณีศึกษาของครูฝึกสอนชาวไทย

บทความนี้อภิปรายวิธีที่ครูฝึกสอนวิชาภาษาอังกฤษชาวไทยให้นิยามการเลือกภาษาที่ใช้ใน ห้องเรียน สิ่งบ่งบอกการใช้งานและข้อจำกัดที่สร้างขึ้นเพื่อการเรียนรู้ และสิ่งนี้กระทบกับตัวตน ในฐานะที่เป็นครูฝึกสอนอย่างไร จากการเก็บข้อมูลการศึกษาเชิงชาติพันธุ์ตามยาวในภาคกลาง ของประเทศไทย บทความนี้จะอธิบายว่าการเลือกภาษาทำหน้าที่เป็น "เทคโนโลยีในการพูดคุย" (Jones, 2016) อย่างไร ที่ทำให้เกิดทั้งสิ่งบ่งบอกการใช้งานและข้อจำกัดในการปฏิสัมพันธ์ของคน เรา รวมถึงวิธีการที่เราประนีประนอมตัวตนเพื่อการปฏิสัมพันธ์ในห้องเรียน นอกจากนี้จะสาธิตว่า ในสังคมที่ทุกวันนี้การฟังพูดอ่านเขียน ถูกกล่อมเกลาโดยเทคโนโลยีดิจิทัลมากขึ้น การเลือกภาษา ไม่เพียงแต่ถูกนิยามผ่านการสนทนาอย่างเหมาะสมตามสถานการณ์ในห้องเรียนเท่านั้น แต่ยังได้ อิทธิพลจากเครือข่ายขยายของการฟังพูดอ่านเขียนทางดิจิทัลของนักเรียนที่นอกห้องเรียนอีกด้วย การฟังพูดอ่านเขียนทางดิจิทัลเป็นวิธีการใหม่ในการแสดงออก การกระทำและการใช้ภาษาที่แทบ จะไม่ได้ใช้เมื่ออยู่นอกห้องเรียน การปฏิบัติตามแนวทางดังกล่าวที่ช่วยสร้างเครือข่ายของการฟัง พูดอ่านเขียนที่แผ่ขยายวงกว้าง จะทำให้เกิดโหนดที่สลับซับซ้อนระหว่างพื้นที่ออนไลน์และไม่ ออนไลน์ ซึ่งที่สุดแล้วจะค่อย ๆ เกิดเป็นพื้นที่เชื่อมโยงกันอย่างเช่นในห้องเรียน

\section{Introduction}

Traditionally, the role of language choice in the classroom has been researched through topics grounded in language practices such as code switching (cf Lin 2013 for an overview) and translanguaging (García 2009; Pennycook 2010) in the classroom, pedagogical issues addressing the effectiveness of L1 and L2 use as the medium of instruction (Cook 2001), and from a more ideological position, outlining policies on the use of language in education (E.g., Tollefson and Tsui 2003). However, in the increasingly complex linguistic reality of modernday society, students are not known for following neatly set out policies on language use, and pedagogically responsible approaches in their choice for the use of an L1 or L2 in the classroom, nor in their wider literacy practices outside the classroom (Nunan 2003; Wei 2017). Students' literacy practices, both inside and outside the classroom, are increasingly mediated by digital technology which allows for new, more ubiquitous ways of expression across various modes while exploring new ways of relating to the world through newly enacted identities (Jones and Hafner 2012). This increased mobility of our practices creates a more fluid conceptualization of traditionally bounded spaces, such as the classroom (Massey 2005) and identities are increasingly distributed over both online and offline spaces in what Blommaert (2013) refers to as superdiversity. These new spaces allow language learners to explore new practices, form allegiances and identities across more diverse translingual networks and create valuable opportunities to use languages which are otherwise scarce 
outside the classroom (Black 2009; Gee 2005; Jones 2010; Lam 2009; Thorne, Fischer and $\mathrm{Lu}$ 2012). More permeable classrooms allow discourses, literacy practices and identities constructed outside the classroom to co-exist alongside the existing classroom practices and influence the ways in which students conceptualize their use English in the classroom.

This paper uses the case study of 16 Thai teacher trainees of English in provincial Thailand to illustrate that the linguistic reality in and beyond the classroom is a rather messy nexus of intersecting literacy practices and discourses in which the choice for one language or another is based on a configuration of interacting factors. I study language choice here as a social phenomenon, a social action that students take in the classroom rather than treating it as a purely descriptive linguistic behavior studied at the clause or sentence level as is traditionally done under the terms code-mixing and code-switching. Drawing on data from a six month Nexus Analysis (Scollon and Scollon 2004), I argue that the choice for one particular language in the classroom is not only contingent on the beliefs, principles and practices normative for classroom interaction, but also influenced by students' individual experience engaging in a wide range of digital literacy practices outside the classroom. I will describe how language choice functions as a 'technology of talk' (Jones 2016) that creates both affordances and constraints for our social interaction and the ways our identity is negotiated in this social interaction. To adequately describe this complex nexus, I adopt a Mediated Discourse Analysis (MDA) approach (Scollon 2002; Scollon and Scollon 2004; Norris and Jones 2005). MDA is a comprehensive approach that studies discourse in action at the micro-interpersonal level as the intersection of the arrangement of social relationships between the actors (interaction order), the discourses in place relevant to the interaction studied and the historical collective of social practices and discourses that the individual actors bring to this moment of action (historical body) (Scollon and Scollon 2004).

\section{2 Spoken Discourse in Action}

Mediated Discourse Analysis (MDA) forms a more comprehensive approach to spoken discourse analysis that shifts the focus from a more traditional textcentered approach to a view of discourse as 'language in use' in social interaction. Jones (2016) argues that the analysis of spoken language, as opposed to spoken discourse, neglects to take into account how discourse and action create the social context in which this action could take place through what Goffman (1974) calls 'framing'. Framing provides valuable cues for the actors to understand and make sense of the wider social context of the interaction through 
cues such as gaze, register, gesture, genre, and of particular importance to this study, language choice. Jones refers to the use of these cues as 'technologies of talk', and as with all tools or technologies that people use, the way people have developed ways of using these tools in social interaction are an intrinsic part of the personal histories actors bring to social interaction. Jones (2016) argues that the social context of interaction is therefore both dynamic, different tools are used in various ways depending on their function, as well as historical, the actors do not isolate their personal histories from these moments of action but rather let their historical bodies inform the way actions, discourse and the tools they use allow a moment of action to take place.

\section{Language Choice as Tool: Thai and English in the Thai Classroom}

I start this section with an observation made in a Thai classroom during a course on English language teaching methodology at a community college in central Thailand. As part of a presentation on a teaching technique a student is called up to the front of the class to act as a student by her classmates to carry out a short skit.

Excerpt 1: dialogue extracted from a recorded classroom observation

1 Presenter: how many people in your family

2 student: $\quad$ well $($.$) there are ten people in my family$

3 whole class: $\mathrm{OH} \mathrm{HOOO}_{\wedge} \mathrm{HO} \mathrm{OO} \vee$

4 student: $\quad\{\mathrm{TH}$ : hear me out you (o.5)\} there is me (.) my father mother grandmother (.) three sisters and three cousins (1.0) \{TH: we have a big house ( 0.5$)$ yeah like that [looks at the class with a smirk]

At first glance, this seems like a mundane example of a classroom performance with a playful class as the audience interacting with the partners while they complete a performed adjacency pair. The students mostly use English to perform a coordinated adjacency pair in lines 1 and 2 . In line 3 , the class responds with a choral utterance of surprise which is followed by a short interjection from the student in Thai to bring their attention back to the activity after which she finishes her explanation in English. At the end of her utterance, she switches back to Thai briefly to provide additional information that they live in a big house. What is interesting to note though is the way in which Thai is used in this interaction is not just an informal remark made by the student to interact with 
the classroom. In fact, the choice for either English or Thai can be seen as a tool that allows the student to frame the social context of the interaction. As Lin (1996) argued, sometimes code switches to a shared L1 in the classroom can signal and provide contextual cues to all participants that one is leaving the existing pedagogical framework behind, using English as the medium of instruction, to deal with more urgent, interpersonal matters such as bringing people's attention back after an interjection (line $4\{\mathrm{TH}$ : hear me out $\}$ ), or providing additional information outside the direct pedagogical framework (\{TH: we have a big house\}). However, the wider context of this performance shows that for the current case it is not the use of Thai that is linguistically marked, but rather the choice to use English to answer the question. Up to the point of this performance all presentations were carried out in Thai with the occasional textbook based question in the skits asked in English. However, the majority of the students opted to answer in Thai instead of English, an observation consistent across six months of observations. In other words, the teaching and learning practices and the Discourse around these classroom literacy practices reflect a shared historical body, a store house of discourses, experiences, routines and social practices of actors or communities (Scollon 2002), in which Thai is used as the language of instruction, and English as a language used sporadically in staged performances to emulate imagined teaching activities. Thai as such is used to frame the socio-interactional context in the classroom and the use of English becomes marked if it is incongruent with the shared historical body.

This better understanding of the context of classroom literacy events also allows us to reinterpret the exchange in lines 3 and 4 and understand better how the choice for Thai or English frames the social context of this event. The choral surprise reaction in line 3 is of particular importance.

This chant is often used among students to express a complex and ambiguous idea of both disapproval or envy and admiration, and was consistently observed through the data collection. During a follow up interview, two students commented on the reason of using the chant.

Excerpt 2: transcription of a focus group interview

259 S1: because normal we use in Thai (.) and when some of them use English it's kind of weird (1.0) kinda strange (.) I mean strange (.) just strange because we know we not use it but when some of us already use English for speak or listening or something like that (.) it's just kinda strange and they just oh why why do you have to do that (.) like that yeah kinda jealous $\{\mathrm{TH}$ : right or not (to $\mathrm{S} 1)\}$

26o S2: $\{\mathrm{TH}:$ yeah but also that we want to be able to do the same $\}$ 
First of all, S1 confirms that the use of English on an English teacher education program at this teacher training college is marked and that it elicits a reaction from the students. However, she also indicates that there must be a clear reason or purpose for the marked use of English (line 259: why do you have to do that). The use of the chant in line 3 could then be interpreted as a way for the class to mark the students' choice of English, instead of Thai, and not as a surprise reaction to the size of her family, which is by no means an exception in Thailand with extended family living with the nuclear family in one house. English then is used as a tool, a technology of talk, to frame the social context of the interaction, thus indicating that this is an English language activity and that English should be used as the language of communication. Although the student is challenged by the class in her attempt to use English to frame a pedagogical moment, she refuses to accept her choice of English as marked. On the contrary, by using a shared Li for this interjection ( $\{\mathrm{TH}$ : hear me out you (0.5)\}), she effectively provides a contextual cue to signal to the class, I am interrupting my English activity to get your attention back to teaching and learning. Even more interesting is how her interjection allows her to finish her explanation and signal to the class that she interpreted the choral reaction from the class as a reaction to her large family, not her marked use of English.

The ways in which students use English or Thai in the classroom are closely tied to the identities they construct as individuals. Gee (2008) argues that language and literacy are basically tools that allow us to say something, do something and be someone and the social practices we engage in are subject to the rules normative for that particular form of interaction. Recent work on identity and language (Agha 2007; Gee 2014; Jones 2016) allows us to view the ways in which we identify ourselves as an interplay between the identities that are invoked by what Gee refers to as big D Discourses - the larger set of beliefs and ideas in society- relevant at the moment of interaction, what Agha calls enregistered identities, and the tools and signs we use and the practices we engage in that allow us to invoke these identities, defined by Agha as emergent identities. The enregistered identities we enact through situational discourses, such as a teacher or a student in the Thai education system, are not just indexed through the uniforms they wear, their location in the classroom, or the qualifications they have earned, but also through the ways they use the tools they have at their disposal to bring about emergent identities. 
The example above already illustrated how one student uses English as a tool to frame her identity as a student teacher who values the use of English as part of the pedagogical practices in the classroom. By her strategic choice for English and Thai to frame different literacy practices, the student signaled that her individual historical body of classroom literacy practices is incommensurable with the shared historical body of the learning community she is part of. Highlighting these moments of friction between individual and shared historical bodies, according to Scollon (2001) creates a way to express a critical ideological stance on, in this case pedagogical practices, and enact a particular identity.

Hall (1996) points out though that there is a constant tension between our conceptual self-enacted through the use of tools, practices, signs and so forth and how our relational self is read by others within the Discourses relevant to interaction at that moment. It seems that in this process of reading other people's identity work, the student teacher community in this study drew on a much larger body of discourses and practices than just those performed at that particular moment of interaction. For instance, unlike the student in the example above, there were certain students who were not challenged in their use of English in the classroom with Thai teachers. These students were among the more competent speakers of English and they were often referred to on the basis of the practices they engaged in outside the classroom. For example, in the process of identification to outsiders or in talk amongst peers, students were often referred to in terms of "she talks to foreigners," "he chats in English," or "she has a boyfriend online." This reference to individual's digital English literacy practices outside the classroom sanctioned the marked use of English in the classroom. For these students, it was accepted to highlight the tension between the shared historical body and the practices and discourses that were incommensurate with the social practices of the individual. In these cases, this tension was not read or did not evoke an identity that reflected an ideological stance, but instead it was seen as an extension of student teachers out of class literacy practices. The influence of out of class digital English literacy practices on determining situationally appropriate use of English or Thai in the classroom reaffirms the notion that technology allows us to conceptualize the bounded classroom as a more fluid space (Massey 2005), as a nexus of relations in which identities are read on the basis of a much wider shared history of literacy practices. Students bring their digital literacy practices, discourses and the identities that they evoke as embodied experiences to the classroom they co-exist alongside the traditional classroom literacy practices. It also illustrates Blommaert's notion of superdiversity where our identities are distributed over offline and online spaces in a fluid conception of interacting social networks. 
In the section above, I argued that there are differences in how English is used in the classroom as a tool to evoke certain identities and how there are differences in how these selves are read by the class. However, it needs to be noted that the marked use of English by certain students did not come without restrictions. Students were very well aware of what Gee (2014) calls configurations of affordances and constraints created by the use of English as a tool to frame their in-class literacy practices. These affordances refer to the things people can do if tools are put to effective use. In the same vain, constraints refer to the ways tools limit our actions when put to use. Since tools neither solely create affordances nor just constraints, Gee refers to these far ends of the spectrum as configurations. In this study, students would, for instance, strategically start presentations in English and switch to Thai at a certain point since both English and Thai provided different configurations of affordances and constraints when put to use. In a follow up focus group interview, students were asked about the process underlying their decision making in their use of English and Thai in their presentation observed in one particular class.

Excerpt 3: transcription of a focus group interview

50 S1: [up to us] (.) up to us (.) actually (1.0) yeah up to us

51 S2: $\{\mathrm{TH}:$ come on tell him $\}$

$5^{2}$ Int: actually (.) you said (.) actually

53 (1.0)

54 S1: (smiles) actually she just wants us to present ehm (.) with Thai mostly (.) because I don't think she understands when we present I say (.) when we present about English yeah

55 Int: ok (1.0) so (.) yeah I observed there was very little English (.) being used during the presentations(.) I mean your group started with [English]

56 S1: [English] and then summarized in Thai

57 Int: yes

$5^{8 \mathrm{~S} 1}$ : yes (1.0) because we know that teacher and my classmate don't understand

This excerpt highlights two important issues. The first issue is that the language of presentation is at the discretion of the students and that in this case the choice for English is a conscious one (line 50: up to us). This creates the impression that using English as the medium of their presentation creates an 
affordance, arguably one that allows them to position themselves as competent speakers of English, and to an extent express their ideological stance on the role of English in their classroom. By their conscious choice to start their presentation in English, the students highlight the incommensurability between their individual historical bodies and the dominant shared historical body of their program which prefers Thai over English in classes taught by Thai teachers.

The second issue that this excerpt highlights is that students are well aware of the temporary nature of this affordance. As Jenny points out in lines 54 and 58 , their decision requires careful consideration since it could negatively impact their performance, and potentially their final grade, in the case their teacher or classmates cannot fully understand the presentation in English. By switching to Thai at a certain point in the presentation, they work out a configuration of affordances and constraints that serves the purpose for that particular moment of action best. At the same time, they aptly manage the salience of the incommensurability between their individual historical bodies and literacy practices and discourses that are normative for the Thai classroom as a historical space (Blommaert and Huang 2009).

The discussion in the previous sections illustrated how teacher trainees' use of English creates certain affordances in the classroom and how it functions as a tool in bringing about emergent identities. However, the conscious choice not to use English and opt for Thai instead should not be seen as default but rather as a choice informed by beliefs and ideas held by the majority of the teacher-trainee community. In other words, not using English in the classroom does not mean that students are not competent speakers of English, or do not wish to identify as such, nor that they subscribe to the idea that English should not be used in the classroom as the medium of instruction. Throughout six months of data collection, it was noted that all students held firm beliefs about the importance of English for pedagogical purposes and the role of English in people's social mobility in Thai society. However, students' use of Thai in and beyond the classroom was governed by a strong discourse that formed the enregistered identity of future teachers or teachers of English in Thai society emphasizing traits and abilities that teacher trainees felt they could not live up to. The following excerpt provides insight into several discourses and practices that inhibit students' self-efficacy and willingness to use English in the classroom. 
Excerpt 4: transcription of a focus group interview

$295 \mathrm{~S}_{4}: \quad$ in the classroom

$296 S_{3}:$ very hard

$297(2.0)$

298 INT: very hard (.) why

$299 \mathrm{~S}_{3}: \quad\{\mathrm{TH}$ : we have to learn $\}$ (makes a gesture of something ongoing)

300 $\mathrm{S}_{4}: \quad$ TH: grammar yes yes $\}$

$301 S_{3}: \quad$ we must use [(1.o) grammar (. ] ehm

$302 \mathrm{~S}_{4} \quad$ [ use grammar ]

$303(1.0)$

304 INT: correctly

305 S3: yeah (.) and everything (.) must be use perfect

a minute later they added:

$383 S_{3}: \quad$ they care about grammar more and more and more

$384 \mathrm{~S}_{4}: \quad\{\mathrm{TH}$ : yes yes $\}$

$385 S_{3}: \quad$ if we talk

$386 \mathrm{~S}_{4}: \quad$ mistake she ehm

$387 \mathrm{~S}_{3}: \quad$ HUH $\uparrow$ HAH $\uparrow[$ imitates the sound the teacher makes] like this

388 S4: the teacher don't like

This excerpt illustrates the strict requirements placed on the correct use of English grammar in the classroom (line 305: and everything (.) must be use perfect) and that mistakes evoke a negative reaction from the teacher illustrated in line 305. These strict requirements explain to an extent why the majority of the students opted to frame both social interaction and pedagogical activities in the classroom in Thai. Within a context in which English is not required and perhaps even discouraged, but highly scrutinized when used, Thai creates the affordance of being evaluated on the content of your message instead of the grammatical accuracy of your content presented in English. Thai thus forms a tool that avoids evoking an identity that reflects shortcomings in one's abilities.

As mentioned above, out-of-class digital English literacy practices play an important role in the classroom-based literacy practices and identifications in the classroom and vice versa. As the excerpt below illustrates, students built on their identities as teacher trainees in their out-of-class digital literacy practices both on social media as well as face to face interaction. The following excerpt highlights some of the affordances and constraints this identification as a teacher trainee of English creates. 
Excerpt 5: transcription of a focus group interview

667 S5: what we (.) because my my profile says $\{\mathrm{TH}$ : studies on $\}$ [English program] 668 S6:

[English program] education

669 S5: I must to check grammar $\{\mathrm{TH}:$ other people will think that I can because I'm an English teacher\}

670 I: ok ok (.) so it's important that you show to the people on Facebook that what you (.) \{ $\mathrm{TH}$ : is it important that the people on Facebook know that you're a teacher and that you have to write correct English\}

671 S5: $\{\mathrm{TH}:[$ important $]\}$

672 S6: $\{$ TH: [important $]\}$

673 S8: $\{\mathrm{TH}:[$ important $]\}$

$674 \quad(3.0)$

$675 \mathrm{~S}_{7}:\{\mathrm{TH}$ : usually if you tell people that you're studying English or becoming a teacher (.) they think that you can speak English\}

676 S6: [yeah yeah] yeah $\{\mathrm{TH}$ : say something\}

$677 S_{5}:$ [yeah yeah]

678 S 7 : $\{\mathrm{TH}$ : that's so smart that you're studying English $\}$

The excerpt above demonstrates that students actively identify as teacher trainees of English on their social media profiles, line 667. It also illustrates how this identification creates expectations from people in the wider community about perceived skills and competencies in English such as line 669 where $\mathrm{S}_{5}$ says " $\{\mathrm{TH}$ : other people will think that I can because I'm an English teacher\}." These expectations create affordances such as mentioned in lines 669 and 678 and evoke emergent identities and claim membership of a community of competent speakers of English. This expectation prompts students to carefully proofread their posts online to potentially live up to this expectation. However, in the majority of cases students opted to use Thai instead of English so as to avoid evoking a negative image of her abilities in English and her overall competence as a student.

Excerpt 6: transcription of a focus group interview

S8: \{TH: I'm afraid I'm making grammatical mistakes (.) I'm afraid of grammatical mistakes and that what I'm saying looks stupid (.) instead of show them that I'm smart (1.0) I'm afraid that when I write it in English and the grammar is incorrect (.) and the people who know it will read that it's wrong (.) I'm afraid they'll think that I'm stupid (.) yeah like that 
This apprehension was also felt by a lot of students both for their in-class performance and out-of-class literacy practices in English and as a result, students often opted for the use of Thai instead of English as the medium of communication in the classroom and beyond, not only because of their fear of not being understood by the teacher, but more out of a feeling of anxiety that they might not be able to live up to the expectations sedimented in the Discourse held by the community outside the university.

\section{Discussion and Conclusion}

This paper set out to discuss the ways Thai teacher trainees of English conceptualize their language choices inside the classroom, the affordances and constraints this creates for their learning and how it affects their identifications as teacher trainees. This case study adds to the growing body of research demonstrating Blommaert's notion of superdiversity in which our literacy practices are increasingly distributed over online and offline sites and how, in the case of this study, teacher trainees create what Leander and Aplin (2014) have explained as a nexus of relations between these practices and discourses. It reaffirmed how digital technology affords new ways of engaging in meaningful literacy practices that allow students to explore new ways of doing, saying and being. This wider bandwidth of multilingual literacy practices has a bearing on how students develop their proficiency levels (de Groot 2017) as well as how they conceptualize language choice. The data from this study reaffirms that language choice is much more than a linguistic choice subject to situationally appropriate practices and instead should be studied within the wider sociolinguistic context of our social interaction. The choice for Thai or English was conceptualized as one of the technologies of talk (Jones 2016) that allowed students to express ideological stances on learning, teaching and the use of English in the classroom. It allowed students to challenge existing practices normative to what Blommaert and Huang (2009) call the historical space. By highlighting what Scollon (2001) calls the incommensurability between the historical space and their individual historical beliefs and ideas about education, students were able to exercise a covert ideological stance critical of current pedagogical practices in an education system that is strictly hierarchical and is averse to forms of criticism (Foley 2005). Students worked out careful configurations of affordances and constraints created by their use of English in the classroom. In doing so they were able to enact identities of competent and able speakers of English while at the same time managing the sensitivity 
of the marked use of English and avoid disproving the positive image held by the wider community about teacher trainees' English language abilities.

\section{References}

Agha, Asif. 2007. Language and Social Relations, Cambridge: Cambridge University Press.

Black, Rebecca. 2009. Online Fan Fiction, Global Identities, and Imagination. Research in the Teaching of English 43.4: 397-425.

Blommaert, Jan. 2013. Ethnography, Superdiversity and Linguistic Landscapes: Chronicles of Complexity. Bristol, England: Multilingual Matters.

Blommaert, Jan and April Huang. 2009. Historical Bodies and Historical Space.Journal of Applied Linguistics 6.3: $267-282$.

Cook, Vivian. 2001. Using the First Language in the Classroom. Canadian Modern Language Review 57.3: 402-423.

Foley, James. 2005. English in...Thailand. RELC Journal 36.2: 223-234.

García, Ofelia. 2009. Education, Multilingualism and Translanguaging in the 21st Century. In Social Justice Through Multilingual Education. Edited by Ajit Mohanty, Minati Panda, Robert Phillipson, Tove Skutnabb-Kangas. 140-158. New Delhi: Orient Blackswan.

Gee, James Paul. 2005. What Would a State of the Art Instructional Video Game Look Like?. Innovate:Journal of Online Education 1.6: 1-8.

Gee, James Paul. 2008. Social Linguistics and Literacies: Ideology in Discourses. New York, NY: Routledge.

Gee, James Paul. 2014. Unified Discourse Analysis: Language, Reality, Virtual Worlds and Video Games. New York, NY: Routledge.

Goffman, Erving. 1974. Frame Analysis: An essay on the organization of experience, New York: Harper and Row.

de Groot, Freek Olaf. 2017. Tracing the Potential of out-of-class Digitally Mediate Language Learning Practice back to the Classroom: A Nexus of Practice Perspective. In Digital Language Learning and Teaching. Edited by Michael Carrier, Ryan Damerow, and Katherine Bailey. 25-37. New York, NY: Routledge.

Hall, Stuart. 1996. Who needs Identity? In Questions of Cultural Identity. Edited by Stuart Hall and Paul Gay. 1-17. Thousand Oaks, CA: Sage.

Jones, Rodney Hale. 2010. Cyberspace and Physical Space: Attention Structures in Computer Mediated Communication. In Semiotic Landscapes: Text, Space and Globalization Edited by: Adam Jaworski and Crispin Thurlow. 151-167. London, England: Continuum. 
Jones, Rodney Hale. 2016. Spoken Discourse. London, England: Bloomsbury Publishing. Jones, Rodney Hale and Christoph Hafner. 2012. Understanding Digital Literacies: A Practical Introduction. London, England: Routledge.

Lam, Eva. 2009. Literacy and Learning across Transnational Online Spaces. E-Learning 6.4: $303-324$.

Leander, Kevin and Beth Aplin. 2014. "After Apple Picking" and Fetal Pigs: The Multiple Social Spaces and Embodied Rhythms of Digital Literacy Practices. In Time and Space in Literacy Research. Edited by Catherine Compton-Lilly and Erica Halverson. 166-182. London, England: Routledge.

Lin, Angel. 1996. Bilingualism or Linguistic Segregation? Symbolic Domination, Resistance and Code-Switching in Hong Kong Schools. Linguistics and Education 8.1: 49-84.

Lin, Angel. 2013. Classroom Code-Switching: Three Decades of Research. Applied Linguistics Review 4.1: 195-218.

Massey, Doreen. 2005. For Space. London, England: Sage.

Norris, Sigrid and Rodney Hale Jones. 2005. Discourse in action: Introducing Mediated Discourse Analysis. London, England: Routledge.

Nunan, David. 2003. The Impact of English as a Global Language on Educational Policies and Practices in the Asia Pacific Region. TESOL Quarterly 37.4: 589-613.

Pennycook, Alistair. 2010. Language as a Local Practice. New York, NY: Routledge.

Scollon, Ron. 2002. Mediated Discourse: The Nexus of Practice. New York, NY: Routledge.

Scollon, Suzanne. 2001. Habitus, Consciousness, Agency and the Problem of Intention. How We Carry and are Carried by Political Discourses. Folia Linguistica 35.1-2: 97-130.

Scollon, Ron and Scollon, Suzie Wong. (2004). Nexus Analysis: Discourse and the Emerging Internet. London, England: Routledge.

Thorne, Steve, Ingrid Fischer and Xiaofei Lu. 2012. The Semiotic Ecology and Linguistic Complexity of an Online Game World. ReCALL 24.3: 279-301.

Tollefson, James and Amy Tsui. 2003. Medium of Instruction Policies: Which Agenda? Whose Agenda? New York, NY: Routledge.

Wei, Li. 2017. Translanguaging as a Practical Theory of Language. Applied Linguistics 39.1: 9-30. 